\title{
TRAINING CUM DEVELOPMENT AND PRODUCTIVITY OF WORKERS IN NIGERIA AGIP OIL COMPANY, PORT HARCOURT, RIVERS STATE
}

\author{
Dr. Porbari Monbari Badom ${ }^{1}$ and Dr. Barinem Wisdom Girigiri ${ }^{2}$ \\ ${ }^{1}$ Department of Sociology, Faculty of Social Sciences, University of Port Harcourt, Rivers \\ State, 500272, Nigeria. Email: philanluv@yahoo.com \\ ${ }^{2}$ Department of Sociology, Faculty of Social Sciences, Rivers State University, Port Harcourt, \\ 500272, Nigeria. E-mail: wisdom4rich@yahoo.com
}

Cite this article:

Badom P.M. and Girigiri B.W. (2021), Training Cum

Development and Productivity of Workers in Nigeria Agip Oil Company, Port Harcourt, Rivers State. African Journal of Social Sciences and Humanities Research 4(4), 4967. DOI: $10.52589 / A J S S H R-$ 9IOMPQJF.

\section{Manuscript History}

Received: 10 Sept 2021

Accepted: 30 Sept 2021

Published: 19 Oct 2021

Copyright $\odot 2020$ The Author(s). This is an Open Access article distributed under the terms of Creative Commons AttributionNonCommercial-NoDerivatives 4.0 International (CC BY-NC-ND 4.0 ), which permits anyone to share, use, reproduce and redistribute in any medium, provided the original author and source are credited.
ABSTRACT: This study investigated the relationship between training and development and productivity of workers of Nigeria Agip Oil Company, Port Harcourt. A review of relevant literature revealed that intellectual response to the issue focused on the relationship between training and productivity in other work organizations and also excludes managerial development. They also failed to specify the method of training, and omitted the development of managers in connection to workers' productivity. This enabled the researchers to identify the gap in knowledge on this area of research, taking cognizance of the various training and development methods, such as on-the-job, off-the-job trainings and development of managers. In the bid to investigate the relationship between the variables, four research questions and four hypotheses were posed to guide the study. Human capital theory was utilized in the clarification and explanation of the causal connection between the study variables. Simple random and random samplings were adopted. The sample size of 316 was determined with the aid of Taro Yamane Statistics, from the population figure of 1500. The study adopted cross-sectional research design and generated data through survey. Data were generated through the questionnaire and analysed using percentage, while chi-square $\left(X^{2}\right)$ statistics was applied to test the hypotheses. The study concluded that there is significant relationship between on-the-job training, off-the-job training, development of managers and productivity of Nigeria Agip Oil Company, Port Harcourt respectively. It also found significant relationship between training and development of workers and inducement by the acquired knowledge and skills to look for better jobs in other organizations. The study thus recommended regular on-the-job training, regular off-the-job training and development of managers, amongst others. The study thus established that training and development significantly cause workers' productivity in Nigeria Agip Oil Company in Port Harcourt.

KEYWORDS: On-the-job Training, Off-the-job Training, Development of Managers, Productivity, Training, Better Job. 


\section{INTRODUCTION}

Human resources managers together with most work organizations have given training and development an important place in work settings. Training and development thus seem to be regarded as a prime target for productivity. Successful candidates placed on their jobs may require training to perform their duties effectively. In work organizations, workers are trained to operate machines and other equipments. This may help in the reduction of scrap and avoidance of accidents in the organizations. Through training, other goals of the organization may likely be achieved. However, "it is not only the workers who need training. Supervisors, managers and executives also need to be developed in order to enable them grow and acquire maturity of thought and action" (Aswathappa, 2002, p. 171).

Another component of a training and development programme is development of managerial staff, which is less skill-oriented but rather gives prominence to knowledge. This include Knowledge about business environment, management principles and techniques, human relations, specific industry analysis and the like is useful for the better management of an organization (Aswathappa, 2002). It is imperative to note that training and development are likely necessary prerequisites for workers to add value to an organization. All categories of employees are trained and developed; while the low cadre workers are trained, the high-level employees, such as supervisors and managers are developed. Thus, training and development are reserved for the employees who are the human assets of work organizations.

In the opinion of Aswathappa (2002), training and development goals should be established after the training needs have been assessed. Such training needs should focus on the expected skills of employees. As an exemplar to anticipated skills, we should be apprised that a new adopted technology in an organization demands new skills. Training and development are essential to prepare the employee to handle more challenging tasks. Employees may also require training owing to possible job transfers and additional role.

After an organization has identified employees' training and development needs, such an organization is left with the choice of training and development method based on the knowledge of the relationship between training and productivity. This is an indication that there are myriads of training and development method to choose from. As opined by Peretomode \& Peretomode (2001), training entails on-the-job and off-the-job methods. As the name applies, on-the-job training methods are used with organizations and are directly job related. They are the most common training methods used by organizations. According to Nwachukwu (1988), training methods avail an employee the following merits:

- The employee is using the same machine, equipment or materials which he will be using after the training.

- He is being subjected to the same environmental constraints under which he will have to operate.

- What he produces while learning is a contribution to the day's effort. 
Similarly, Mathis and Jackson (1982) presented the following as common merits of on-thejob training:

- The importance of learning by doing is well recognized.

- Effective training can be tailored to fit each trainee's background attitudes, needs, expectations, goals and future assignment.

- On-the-job training is not as time consuming.

- The employee's development is influenced to a large extent by the immediate expectations in the training situation.

On the other hand, off-the-job training refers to training methods ranging from vestibule, conference or discussion, case study, role playing, lectures, etc. They are trainings carried out off the job. Thus, such trainings may be given at different environments. Cole (2004) argued that off-the-job training methods have the following merits:

- Useful for factual information (lectures/talks);

- Useful for developing social skills (role playing exercises);

- A safe way to practice key skills.

In addition, management development technique called simulation methods is a widely adopted used oriented development technique (Peretomode \& Peretomode, 2001). Management development method include case study, role playing, the n-basket technique, business games, coaching, position rotation, managerial modeling etc.

The curiousness of this researcher is derived from the observation of the priority level which organizations place training and development. To buttress the priority given to management development, Aswathappa (2002) opined that:

- Management development programmes provide considerable intellectual stimulation.

- Secondly, we acquire a nodding acquaintance with new concepts and new development in the area of managerial techniques.

- The third benefit is the embellishment of one's vocabulary.

These views have therefore left one curious about what it can transcend to. It therefore behooves, this researcher to investigate if there is a relationship between training and development methods and workers' productivity in the Nigeria Agip Oil Company in Port Harcourt.

In addition, it is likely the case that workers who acquired skills and knowledge from an organization in course of training and development given to them may abandon the organization for another better jobs in others promising organizations. Such jobs are considered better because of the higher level of pay and other, pecuniary cum welfare provisions available which are different from what was offered in the other organization that trained him or her. 


\section{Statement of the Problem}

All work organizations anticipate success through management of the human resources. This point out that productivity is the basis of success. Every organization's management desires the same thing in organizations; management strives to get the human resources to make things happen in a productive way, so that the business prospers and the people thrive (Torrington, Hall \& Taylor, 2008). This means that inadequacy in skill; knowledge and ability are some of the factors responsible for low productivity in organizations. Eneh, Inyang \& Ekpe (2015) stressed that cases abound where individual workers bring to the organization different perspectives and ideas which in working life are averse or will work contrary to the goals of the organization. Besides, the contemporary world has witnessed technological advances taking place in work organizations; in recent times, there have been rapid technological changes and automation in Nigeria Agip Oil Company in Port Harcourt, which have necessitated the need for training and development of workers. There is also the need to know if a trained and developed worker will stay with the organization or not. This is important owing to the significant influence which employees exert over the productivity of the system (Ihunda, 2002).

In addition, most work organizations have the assumption that a new entrant should be trained to be acquainted with a particular work culture, in order to contribute to the productivity of the organization. From series of accidents and complaints against workers of Nigeria Agip Oil Company in Port Harcourt and the craving for training and development, the researcher is curious about the relationship between training and development and productivity. At first, we sensed that researches have been conducted in this area. This compelled the researchers to review the literature relevant to this area of study and found that intellectual response on the issue of training and productivity had been focused on other work organizations. Ekundayo (2015) studied the impact of training and development on workers productivity: a study of selected oil service companies in Port Harcourt. The study was quantitative and data were collected from 109 as sample size derived from the population figure of 150. Inspite of the claim by this study, it did not specify the methods of training and development, such as on-the-job training, off-the-job training and development techniques. Also, the researcher only stated that he studied oil companies in Port Harcourt. There was no mention of any given company by the researcher. Also, considering the large number of staff of each oil company in Port Harcourt, the stated 109 as sample size, to our minds renders the sample size questionable. This thus created a gap which this study sought to fill.

Besides, Eneh, Inyang and Ekpe (2015) studied the impact of job training on workers' efficiency and productivity: A study of Pamol Nigeria Limited, Calabar. The study adopted a quantitative method. However, the researcher did not specify the kind of training that yielded its result. This is because all the training methods are not the same. This therefore created a lacuna for this study to fill.

Also, Gabriel \& Rowland (2020) did a study on training and effectiveness in Port Harcourt City Council, Rivers State. The data which yielded the results published by these researchers were collected from the staff of the Port Harcourt City Council, in which case it can not be generalized to other organizations. It cannot, therefore, speak for the Nigeria Agip Oil Company. This therefore created a gap which the present study sought to fill. 
From the foregoing intellectual attention given to related problems, and to the best of our knowledge, there has been no work in the area of training and development and productivity of workers in Nigeria Agip Oil Company, Port Harcourt. It is this gap which this study filled.

\section{Objectives of the Study}

The general objective of this study was to investigate the relationship between training and development and workers' productivity in Nigeria Agip Oil Company, Port Harcourt. Therefore, the specific objectives of the study were:

1. To investigate the relationship between on-the-job training and productivity of workers of Nigeria Agip Oil company, Port Harcourt.

2. To examine the relationship between off-the-job training and productivity of workers of Nigeria Agip Oil company, Port Harcourt.

3. To investigate the relationship between the development of managers and productivity of workers of Nigeria Agip Oil company, Port Harcourt.

4. To examine the relationship between training and development of Nigeria Agip Oil Company workers in Port Harcourt and inducement to look for better jobs elsewhere with the acquired knowledge and skills.

\section{Research Questions}

The following questions guided the study:

1. What is the relationship between on-the-job training and productivity of workers of Nigeria Agip Oil Company, Port Harcourt?

2. What is the relationship between off-the-job training and productivity of workers of Nigeria Agip Oil Company, Port Harcourt?

3. What is the relationship between the development of managers and productivity of workers of Nigeria Agip Oil Company, Port Harcourt?

4. Is there relationship between training and development of Nigeria Agip Oil Company workers in Port Harcourt and inducement by the acquired knowledge/skills to look for better job in other organization(s)?

\section{Hypotheses of the Study}

The following hypotheses were formulated to guide the study:

1. There is no significant relationship between on-the-job training and productivity of workers of Nigeria Agip Oil Company workers in Port Harcourt.

2. There is no significant relationship between off-the-job training and productivity of workers of Nigeria Agip Oil Company workers in Port Harcourt.

3. There is no significant relationship between development of managers and productivity of workers of Nigeria Agip Oil Company workers in Port Harcourt. 
4. There is no significant relationship between training and development of Nigeria Agip Oil Company workers in Port Harcourt and inducement by the acquired knowledge and skills to look for better jobs in other organizations.

\section{LITERATURE REVIEW}

In this section, we are practically concerned with the conceptual and empirical review of literature. By conceptual review, the concepts of the study; such as productivity, training and development are reviewed and conceptualized, while empirical review gives attention to the empirical works done by other researchers taking cognizance of the variables of the study. This will enhance a proper understanding of the variables of this work, and make clearer the gap which other studies left and which this study sought to fill.

\section{Worker Productivity}

Productivity: Productivity in the opinion of Peretomode \& Peretomode (2001) is a major concern of management in any organization. It is this concern for increased productivity that underlies the efforts by organizations to select from a pool of qualified candidates or persons who are most suited for the job. As a day-to-day concern of managers, productivity indicates the overall efficiency of the organization (Donnelly, Gibson \& Ivancevich, 1984).

Similarly, Greenberg (1996) argued that in the organizational context, employee productivity is usually defined as the extent to which a member of the organization contributes to the achievement of the set goals of the organization. In consideration of the fact that an organization expends some cost in anticipation of benefits. Mathis \& John (2003) defined employee productivity as a measure of the quantity and quality of work done, considering the cost of the resources used. Furthermore, in the opinion of Bond \& Fox (2007), measures of employee productivity includes: quantity of work, timeliness of work, quality of work i.e. the quality of work produced in term of standards, use of resources/efficiency, productive work habits, customer (external and internal) impact/value add, self reliance, alignment and compliance.

Deduced from the foregoing, it is then easy to conceptualize productivity. For this study, productivity is taken to mean the efficient and quality contributions of a worker that enhances the achievement of goals of the organization without suffering major loss in the costs and time that were used. It is generally concerned with the extent to which a worker contributes to the achievement of set goals for the organization (Greenberg, 1996).

\section{Training and Development}

Training and development have been variously defined by several authors. This is because of their importance to work organizations. Training in the opinion of Mondy, Noe \& Premeaux (2002) refers to the generality of activities which are designed by an organization to provide learners with the knowledge and skills needed for the execution of their present jobs. This means that workers are in need of acquiring more knowledge and skills required by the job in order to be more efficient. Similarly, "training is the process of equipping the workforce with the necessary knowledge, skills and attitude to tackle the job responsibilities" (Gabriel \& Rowland, 2020). 
This view is also expressed in Armstrong (2001) that training is a systematic way of acquiring the knowledge and skills including the attitudes required of an individual worker to perform a job task adequately. It is therefore agreed in this work that training is concerned with learning key skills and acquiring knowledge and behaviour required to perform a job task efficiently and also to reduce deficiency.

There are, however, sundry methods of training workers. This includes on-the-job and offthe-job training methods. On-the-job training is concerned with the teaching of the specific skills and knowledge on the job. Such skills and knowledge are directly concerned with skills required on the job and also encourages learning by doing. It is conducted at the site and in the context of the job (Aswathappa, 2002). On-the-job training methods include, orientation training, job instruction training, apprenticeship training, internships and assistantships, job rotation and coaching.

Off-the-job on the other hand, refers to training conducted off the site; the training is conducted in an environment different from the particular workplace. Off-the-job training methods include: vestibule, lecture, special study, films, television, conference or discussion, case study, role playing simulation, programmed instruction and laboratory training (Aswathappa, 2002). There are a number of benefits associated with training, both on-the-job and off-the-job.

Furthermore, it is not only workers who require training, supervisors, managers and executives also need to be developed. This is to make them grow and acquire maturity of thought and action (Aswathappa, 2002). In this way, managers and other senior workers are developed. "Development is an unfolding process that enables people to progress from a present state of understanding and capability to a future state in which higher level, skills, knowledge and competencies are required", (Armstrong, 2006 p. 570). Development is less skill-oriented; it is rather based on knowledge about management among others. Management development methods range from special meetings and conferences, sensitivity method, mentoring, business game and position rotation.

\section{Empirical Works Bordering on Relationship between Training and Development and Workers Productivity}

Training has attracted the attention of researchers, to study the relationship of training and employee productivity in different context and organizations.

Ekundayo (2015) studied the impact of training and development on workers productivity: A study of selected oil service companies in Port Harcourt. The study adopted the quantitative method and data were collected from one hundred and nine (109) respondents as sample size derived from the population figure of one hundred and fifty (150). Inspite of the claim by this researcher that it studied training and development; it failed to specify the methods of training and development, such as on-the-job training methods, off-the-job training methods and development techniques. Also, the researcher only stated that he studied oil companies in Port Harcourt. Thus, readers of the study do not know the exact oil company studied. In addition, the population of the study given by the researcher, considering the large number of staff of each oil company in Port Harcourt, to my mind renders the population and sample size questionable. In which case there could be sampling error. This in my estimation created a lacuna, which this study intends to fill. 
In another study, Nwaeke \& Obiekwe (2017) "examined the impact of manpower training and development on organizational productivity and performance a theoretical review" (sic). The paper observed that improved productivity, effectiveness and efficiency of organizations rely solely on skills, attitudes, knowledge and competencies of their employees which are made possible through training and development. This study adopted qualitative methodology and failed to specify the particular methods of training and development that yielded such result. This created a gap for this study to fill.

Furthermore, Don-Baridam (2013) studied productivity and staff development in corporate organizations. The study emphasized that "no organization can survive without effective utilization of people to achieve both the objectives of the enterprise and the satisfaction and development of the employees. Don-Baridam (2013) quoted (Broadhust, 2012; Dukakis, 2002) of having stressed that "employee development has become increasingly vital to the success of modern organizations because rapid changes in technology require that employees possess the knowledge and skills needed to cope with the new processes being introduced. This study adopted a descriptive method; as such it requires a quantitative study to validate its claims.

Similarly, Tahir, Yousafzai, Jan \& Hashim (2014) investigated the impact of training and development on employees' performance and productivity. The study found significant relationship between the variables of that study. It pointed out that the main objective of every organization is to improve performance of employees. Employees can improve their performance through training and development. This study examined the case of United Bank Limited, Pashawar City, KPK, Pakistan.

It therefore presented a limitation as it confined to respondents of United Bank in Pakistan.

This is also similar to a study centered on impact of training on employee's performance and productivity in construction industry in Neyestani (2014). The study stressed that large companies are required to train and develop their employees so as for them to become experts. When an individual worker is an expert, he or she performs creditably and can thus improve the company's productivity.

"Training is a key element for improved performance because it can increase the level of individual and organizational competency," (Ibid). However, its descriptive approach demands validation by the quantitative method. Hence, this study intended doing that.

Also, Gabriel \& Rowland (2020) explored the relationship between training and employee effectiveness in Port Harcourt City Council, Rivers State, Nigeria. The study was designed as a quasi-experimental research design and cross-sectional method adopted. It was a quantitative study. The study found a significant and positive relationship between training and timeliness of work. It also found a significant relationship between training and quality of work in Port Harcourt city Council in Rivers State, Nigeria. The study therefore concluded that "training significantly influences employee effectiveness. This study is another contribution to the issue of training and relationship with employee productivity. However, the data that produced the result were solely dependent on the employees of the Port Harcourt City Council. 


\section{Theoretical Framework}

This study utilized Human Capital theory which was propounded by Smith (1973) as a form of improvement in human capability which is geared towards productivity, and was later reinforced by Schultz (1961). Human capital theory postulates that human resource is an important asset capital which organizations invest in, for the sole purpose of benefiting from. Human resources are regarded as assets to organizations and as assets organizations tap from their wealth of knowledge and skills. Such potentials of workers contribute to the well-being of organizations. In work organizations, individual workers enter organizations with their potentials; they have their specific knowledge, skills and abilities required by the organizations to perform creditably. However, not all who are employed in spite of the early signs of possessing required potentials finally live up to expectations. Also, the dynamic nature of work organizations necessitated by more modern and changing technology requires new and compatible knowledge, skills and abilities to get certain tasks done at work.

When individual workers lack the requisite knowledge to perform tasks in the organizations, certain problems will no doubt be experienced. Their may be problems of labour turnover, which invariably will cause the organization the predicament of administrative cost, recruitment cost, induction cost, selection cost etc. This is the reason an organization measures an employee's performance and productivity level (Guest, 1997; Delaney \& Huselid, 1996).

After the measurement of an employee performance and a resulting training and development need identification, the individual worker will be trained and developed by the organization were he or she is attached to. Itami, Snell et al., \& Wright et al (as cited in Rajabhat, 2017) argued that knowledge, skills and abilities are taken as invaluable assets and tools for sustainable organization. In other words, "a more educated better-trained person is capable of supplying a larger amount of useful productive effort than one with less education and training" (McConnel, Brue \& Macpherson, 2009, p.85).

Becker (as cited in Rajabhat, 2017) stressed that "human capital can be accumulated in different forms of education, training. This includes on-the-job training methods, off-the-job training method and development methods. Through such forms, employees gain knowledge, skills and abilities in different ways. Organizations invest in human capital so as to enable them provide a positive value to the organization. This will enhance productivity. It is pertinent to stress that the training and development given to workers are expected to yield productivity to the organization. Every organization expects a return on investment. This is why trained workers become more productive and efficient to the organization.

However, "human capital theory states that a different level of education and training contribute to a different level of wages and salaries, the more knowledge, skill and ability, the more likely to get a better job" Blair (cited in Rajabhat, 2017, p.242). This point out that some employees will earn a higher potential through training and development in a particular organization and workers will want to look for better positions in other more advanced organizations with the knowledge and skills earned thereto. 


\section{MATERIALS AND METHODS}

The study utilized the cross-sectional research design and generated data through survey method. This is because a survey research makes a correlation research design possible. The study also relied on primary and secondary sources of data. Thus, questionnaire was administered to three hundred and sixteen (316) respondents who formed the sample of the study that was determined with the aid of the taro yamane statistics which statistical formula is as follows:

$$
n=\frac{N}{1+N(e)^{2}}
$$

Where;

$$
\begin{array}{lll}
\mathrm{N} & = & \text { the sample size } \\
\mathrm{N} & = & \text { population } \\
\mathrm{e} & = & \text { level of precision }
\end{array}
$$

Such sample size was systematically drawn from the population of the study. The population of the study is the population of Nigeria Agip Oil company workers in Port Harcourt. According to the human resource department of Agip (2020), the company has a total of 1500 workers. This therefore is the population figure.

Also, the study adopted the stratified random and simple random sampling techniques. Stratified random sampling is a method of sampling in which sample elements are selected separately from population strata in exact proportion. To their representation in the population, the staff population of Nigeria Agip company is stratified within the continuum of managers, supervisors, rank and file. Also, through the simple random sampling every sample of elements was selected by chance through a random process. The retrieved questionnaires were analyzed using descriptive statistics and frequency distribution, as well as chi-square statistics $\left(\mathrm{x}^{2}\right)$ that was used to test the hypotheses. The chi-square formula is as follows:

$$
X^{2}=\frac{(f o-f e)^{2}}{f e}
$$

where;

$$
\begin{array}{lll}
X^{2} & = & \text { Chi-Square } \\
\mathrm{FE} & = & \text { Expected Frequency } \\
\mathrm{FO} & = & \text { Observed Frequency }
\end{array}
$$

The decision rule is to reject the null hypothesis if the chi-square $\left(X^{2}\right)$ calculated value is greater than the table value which is 0.05 significance level, otherwise retain the stated hypothesis. 
African Journal of Social Sciences and Humanities Research

ISSN: 2689-5129

Volume 4, Issue 4, 2021 (pp. 49-67)

www.abjournals.org

Table 3: Frequency Distribution of Demographic Variables (June 28, 2020).

$\begin{array}{llll}\text { S/N. } & \text { Variable } & \text { N } & \text { \% } \\ 1 . \quad \text { Sex } & & \\ & \text { Male } & 217 & 68.67 \\ & \text { Female } & 99 & 31.33 \\ \text { 2. } & \text { Age } & & \\ & 21-30 & 49 & 16 \\ 31-40 & 68 & 21 \\ & 41-50 & 80 & 25 \\ 51-60 & 75 & 24 \\ \text { 61-70 } & 44 & 14 \\ \text { Marital Status } & & 66.46 \\ \text { Married } & 210 & 22.15 \\ \text { Single } & 70 & 3.48 \\ \text { Separated/Divorced } & 11 & 7.91 \\ \text { Widow } & 25 & \\ \text { Educational Qualification } & & 50.63 \\ \text { First Degree } & 160 & 24.69 \\ \text { HND } & 78 & 11.07 \\ \text { Professional Degree } & 35 & 8.23 \\ \text { PGD } & 26 & 4.75 \\ \text { FSLC } & 15 & 0.63\end{array}$

5. Work Experience

$\begin{array}{lll}1-5 \text { years } & 35 & 11.08 \\ 6-10 \text { years } & 62 & 19.62 \\ 11-15 \text { years } & 99 & 31.32 \\ 16-20 \text { years } & 70 & 22.15 \\ 21-25 \text { years } & 22 & 6.96 \\ 26-30 \text { years } & 28 & 8.87 \\ \text { Rank } & & \\ \text { Junior } & 161 & 50.95 \\ \text { Supervisors } & 70 & 22.15 \\ \text { Managers } & 65 & 20.57 \\ \text { Executives } & 20 & 6.33\end{array}$


African Journal of Social Sciences and Humanities Research

ISSN: 2689-5129

Volume 4, Issue 4, 2021 (pp. 49-67)

www.abjournals.org

\section{RESULTS}

\section{On-the-Job Training and Productivity of Workers}

S/N Items

1. I feel that an orientation training given to $116(36.71)$ workers makes them

Acquire the knowledge to be productive.

2. I feel that internship training given to workers enable them acquire the knowledge to make them contribute efficiently to the organization.

3. When workers receive apprentice training, it makes them contribute efficiently to the organization.

4. Coaching as an on-the-job training method makes workers contribute efficiently to the achievement of the organization's goals.

5. Job rotation as an on-the-job training method enables workers to bring in quality and efficient contributions which 140( 44.30) 116 40

132

(41.77)

50

160

128 (40.51)

$94(29.75)$ 130 53 (16.77)
SD

$12(3.80)$ enhance the achievement of the organization's goals.

Table 3.1: Contingency table showing Observed and Expected Frequencies

\begin{tabular}{|l|l|l|l|l|}
\hline S/N & $\begin{array}{l}\text { STRONGLY } \\
\text { AGREE }\end{array}$ & AGREE & DISAGREE & $\begin{array}{l}\text { STRONGLY } \\
\text { DISAGREE }\end{array}$ \\
\hline 1. & $116(126)$ & $120(125.2)$ & $68(45.8)$ & $12(19)$ \\
\hline 2. & $140(126)$ & $116(125.2)$ & $40(45.8)$ & $20(19)$ \\
\hline 3. & $120(126)$ & $132(125.2)$ & $50(45.8)$ & $14(19)$ \\
\hline 4. & $160(126)$ & $128(125.2)$ & $18(45.8)$ & $10(19)$ \\
\hline 5. & $94(126)$ & $130(125.2)$ & $53(45.8)$ & $39(19)$ \\
\hline
\end{tabular}

$X^{2}=80.592$

Table value at $0.05=21.026$ with 12 degrees of freedom. Since the computed value of $X^{2}$ is greater than the table value, we therefore rejected the null hypothesis but retained the alternate hypothesis, upholding that there is significant relationship between on-the-job training and productivity of workers. 


\section{Off-the-Job Training and Productivity Of Workers}

\begin{tabular}{|c|c|c|c|c|c|}
\hline $\mathbf{S} / \mathbf{N}$ & Items & $\mathbf{S A}$ & A & D & SD \\
\hline 1. & $\begin{array}{l}\text { If workers are given the case study training, } \\
\text { I feel that they will contribute efficiently to } \\
\text { the achievement of the target goals of the } \\
\text { organization. }\end{array}$ & $\begin{array}{c}102 \\
(32.28)\end{array}$ & $\begin{array}{c}156 \\
(49.37)\end{array}$ & $\begin{array}{c}48 \\
(15.19)\end{array}$ & $\begin{array}{c}10 \\
(3.16)\end{array}$ \\
\hline 2. & $\begin{array}{l}\text { Vestibule training given to a worker makes } \\
\text { him or her contribute efficiently to help the } \\
\text { organization achieve productivity }\end{array}$ & $\begin{array}{c}142 \\
(44.94)\end{array}$ & $\begin{array}{c}128 \\
(40.50)\end{array}$ & $\begin{array}{c}26 \\
(8.23)\end{array}$ & $\begin{array}{c}20 \\
(6.33)\end{array}$ \\
\hline 3. & $\begin{array}{l}\text { Role playing training method given to } \\
\text { workers enable them contribute efficiently } \\
\text { to the target goals of the organization. }\end{array}$ & $\begin{array}{c}124 \\
(39.25)\end{array}$ & $\begin{array}{c}150 \\
(47.47)\end{array}$ & $\begin{array}{c}21 \\
(6.64)\end{array}$ & $\begin{array}{c}21 \\
(6.64)\end{array}$ \\
\hline 4. & $\begin{array}{l}\text { I feel that simulation (the use of equipment } \\
\text { or technique that duplicates as possible the } \\
\text { actual conditions encountered on-the-job) } \\
\text { enable workers to contribute efficiently to } \\
\text { the organization. }\end{array}$ & $\begin{array}{c}120 \\
(37.98)\end{array}$ & $\begin{array}{c}146 \\
(46.20)\end{array}$ & $\begin{array}{c}42 \\
(13.29)\end{array}$ & $8 \quad(2.53)$ \\
\hline 5. & $\begin{array}{l}\text { I feel that if a worker is given laboratory } \\
\text { training, he or she will contribute to the } \\
\text { productivity of the organization. }\end{array}$ & $\begin{array}{c}132 \\
(41.77)\end{array}$ & $\begin{array}{c}116 \\
(36.71)\end{array}$ & $\begin{array}{c}58 \\
(18.35)\end{array}$ & $\begin{array}{c}10 \\
(3.17)\end{array}$ \\
\hline
\end{tabular}

Table 3.2: Contingency table showing Observed and Expected Frequencies

\begin{tabular}{|l|l|l|l|l|}
\hline S/N & $\begin{array}{l}\text { STRONGLY } \\
\text { AGREE }\end{array}$ & AGREE & DISAGREE & $\begin{array}{l}\text { STRONGLY } \\
\text { DISAGREE }\end{array}$ \\
\hline 1. & $102(124)$ & $156(139.2)$ & $48(39)$ & $10(13.8)$ \\
\hline 2. & $142(124)$ & $128(139.2)$ & $26(39)$ & $20(13.8)$ \\
\hline 3. & $124(124)$ & $150(139.2)$ & $21(39)$ & $21(13.8)$ \\
\hline 4. & $120(124)$ & $146(139.2)$ & $42(39)$ & $8(13.8)$ \\
\hline 5. & $132(124)$ & $116(139.2)$ & $58(39)$ & $10(13.8)$ \\
\hline
\end{tabular}

$X^{2}=54.954$

Table value $=21.026$ at 0.05 significance level and with 12 degrees of freedom. Comparatively, the calculated chi-square $X^{2}$ is greater than the table value. Therefore, we rejected the null hypothesis and retained the alternate form, thus, upholding that there is significant relationship between off-the-job training and productivity of workers. 


\section{Development of Managers and Productivity}

\section{S/N Items}

\section{SA}

1. When managers attend special meetings and conferences, it makes them contribute to efficiency and quality of the organization.

97

(30.70)

A

143

$(45.25)$

D

65

(20.57)

$\begin{array}{cccc}122 & 140 & 38 & 16 \\ (38.61) & (44.30) & (12.03) & (5.06)\end{array}$

to the achievement of target goals of the organization.

3. I feel that when managers undergo mentoring, it enables them increase the productivity of the organization.

4. Business games as a development method, enables managers to acquire decision making skills that enhance productivity in the organization.

5. When managers are involved in position rotation, I feel that this will make them garner the required knowledge and thus increase the productivity of the organization.

$\begin{array}{cccc}132 & 128 & 47 & 9 \\ (41.77) & (40.51) & (14.87) & (2.85)\end{array}$

$\begin{array}{llll}92 & 136 & 68 & 20\end{array}$

(29.11) (43.04) (21.52)

$\begin{array}{ccc}160 & 72 & 56 \\ (50.63) & (22.78) & (17.72)\end{array}$

Table 3.3: Contingency table showing Observed and Expected Frequencies

\begin{tabular}{|l|l|l|l|l|}
\hline S/N & $\begin{array}{l}\text { STRONGLY } \\
\text { AGREE }\end{array}$ & AGREE & DISAGREE & $\begin{array}{l}\text { STRONGLY } \\
\text { DISAGREE }\end{array}$ \\
\hline 1. & $97(120.6)$ & $143(123.8)$ & $65(54.8)$ & $11(16.8)$ \\
\hline 2. & $122(120.6)$ & $140(123.8)$ & $38(54.8)$ & $16(16.8)$ \\
\hline 3. & $132(120.6)$ & $128(123.8)$ & $47(54.8)$ & $9(136.8)$ \\
\hline 4. & $92(120.6)$ & $136(123.8)$ & $68(54.8)$ & $20(16.8)$ \\
\hline 5. & $160(120.6)$ & $72(123.8)$ & $56(54.8)$ & $28(16.8)$ \\
\hline
\end{tabular}

Chi-square calculated value $=78.58$

Table value of $X^{2}$ at 12 Degrees of freedom $=21.026$. This shows that the calculated chisquare is greater than the critical table value. This therefore necessitated the rejection of the null - hypothesis and the retaining of the alternate hypothesis. Therefore, we uphold that there is a significant relationship between development of managers and productivity of the organization. 
Training and Development of Workers, and the Inducement By the Acquired Knowledge and Skills To Look For Better Jobs In Other Organizations.

\section{$\mathbf{S} / \mathbf{N} \quad$ Items}

1. IWhen employees are trained and developed, they acquire specific knowledge that will likely be required by other organizations.

2. I feel that after an employee has received training and development, he or she will look for better jobs in other organizations.

3. Organizations train and develop employees to look for outside jobs.

\section{SD}

10834.18

A

3812.03

4714.87

14947.15

$82 \quad 25.95$

28

8.86

14044.30

$113 \quad 35.76$

Table 3.4: Contingency Table showing Observed and Expected Frequencies

\begin{tabular}{|l|l|l|l|l|}
\hline S/N & $\begin{array}{l}\text { STRONGLY } \\
\text { AGREE }\end{array}$ & AGREE & DISAGREE & $\begin{array}{l}\text { STRONGLY } \\
\text { DISAGREE }\end{array}$ \\
\hline 1. & $108(60.3)$ & $55(43.3)$ & $117(135.3)$ & $36(77.10)$ \\
\hline 2. & $38(60.3)$ & $47(43.3)$ & $149(135.3)$ & $82(77.10)$ \\
\hline 3. & $35(60.3)$ & $28(43.3)$ & $140(135.3)$ & $113(77.10)$ \\
\hline
\end{tabular}

Chi-square calculated value $=108.438$

Table value of chi-square at 6 degrees of freedom at 0.05 level of significance is 12.592 .

$108.438>12.592$

Therefore, we rejected the null - hypothesis and retained the alternate hypothesis which established the fact that there is a significant relationship between training and development of workers and inducement by the acquired knowledge and skills to look for better jobs in other organization.

\section{DISCUSSION}

The study sought answers to the research questions which border on the investigation of the relationship between training and development and productivity of workers. The first finding is relatively derived from research question one. Five statements bordering on on-the-job training methods were utilized, in which case we operationally connected the concepts and values to observations. In this way we revisited the first research question and its corresponding hypothesis was tested. It was found that there is significant relationship 
between on-the-job training and workers' productivity in Nigeria Agip Oil Company, Port Harcourt. This means that training and development cause workers to be productive.

Based on the operationalisation of the variable on-the-job training, five training methods which became the values were used for "on-the-job training". They are: orientation training, internship training, and apprentice training, coaching and job rotation. This finding corroborates the finding in Ekundayo (2015) which stressed that there is positive significant relationship between training and workers' productivity.

Secondly, the study found that there is significant relationship between off-the-job training and workers' productivity. In essence, it points out that off-the-job training given to workers cause their productivity in organizations.

The findings corroborated the findings in Nwakobi (2015). After conceptualization the variable was operationalized and the following values were used for off-the-job training. They include, case study training vestibule training, role playing, simulation, and laboratory training.

Thirdly, it is also established in this study that there is significant relationship between development of managers and productivity. It is pertinent to stress that managers are developed in various ways. This reveals development methods which invariably cause organizational productivity.

The empirical aspects of the variable were considered. The researcher specified the operations that indicated the value of cases of management development. They were confined to special meetings and conferences, sensitivity method, mentoring, business game and position rotation. The responses on each of these formed the general opinion and findings of the relationship between management development and productivity.

Finally, another startling discovery in the study revealed a significant relationship between training and development of workers and the inducement by the acquired knowledge/skills to look for better jobs in other promising organizations. Three cases were specified as the operations for the fourth research question.

\section{CONCLUSION}

Sequel to the discovery made in the study, we concluded that:

1. There is a significant relationship between on-the-job training and workers' productivity in Nigeria Agip Oil Company, Port Harcourt.

2. There is a significant relationship between off-the-job training and workers' productivity in Nigeria Agip Oil Company, Port Harcourt.

3. There is a significant relationship between development of managers and productivity in Nigeria Agip Oil Company, Port Harcourt. 
4. There is a significant relationship between training and development of Nigeria Agip Oil Company workers in Port Harcourt and inducement by the acquired knowledge/skills to look for better jobs in other organizations.

\section{RECOMMENDATIONS}

The following recommendations are hereby proffered:

1. Regular on-the-job training: It is the knowledge and skills garnered from the training, which among other factors bring about productivity, therefore organizations should train their workers regularly.

2. Regular off-the-job training: There should be regular training of workers through the off-the-job training methods. This will enhance the acquisition of wider and required knowledge and skills to perform duties efficiently. This should be based on the need identification.

3. Development of managers should be periodic: organizations should make it a routine exercise to periodically develop managers. This will increase their managerial knowledge and skills and enable them to adapt to changing situations in work organizations.

4. Workers who are identified as those who need training and development to contractually agree to stay with the organization for some reasonable period after their being trained and developed. This will make them to utilize the acquired new knowledge and skills to cause productivity in the organization. A worker who absconds with the acquired knowledge will not bring about productivity in the organization that trained him or her.

5. Regular publication of need for training and development: The human resource department should regularly present a diagnosis of prevailing conditions in the organizations and identifies needs for training and development. Only in this case where individual workers who require training and development are identified, will there be productivity.

6. Training and development programmes should be planned to enhance productivity: The organization should plan the training and development programme towards the job needs so as to enhance productivity. In this way, it should prepare towards the job functions of individual employees who have been identified to be in need of training and development. 


\section{REFERENCES}

Abomeh, O. S. \& Nwakoby, N. P. (2015). Effects of training on employees' productivity in Nigeria insurance industry. British journal of economics, management and trade. 7(3), 227-235.

Armstrong, M. (2001). Handbook of human resource management practice ( $8^{\text {th }}$ ed.). London: Kogan page.

Armstrong, M. (2006). A handbook of human resource management practice (10 ${ }^{\text {th }} \mathrm{ed}$.). London, Philadephia: Kogan page.

Aswathappa, K. (2002). Human resource and personnel management: text and cases. ( $3^{\text {rd }}$ ed.). New Delhi: Tata McGraw-Hill publishing company Ltd.

Bond, T. \& Fox, C. (2007). Applying the rash model: fundamental measurement in human sciences. New Jersey: Lawrence Album associate Publishers.

Cole, G. A. (2004). Management theory and practice (6 ${ }^{\text {th }}$ ed.). U. K.: T. J. International, Padstow, Cornwall.

Delaney, J. T. \& Huselid, M. A. (1996). The impact of human resource management practices on perceptions of organizational performance. Academy of management journal. 39,949-969.

Don-Baridam, L. (2013). Productivity and staff development in corporate organizations. IOSR journal of business and management. 13 (6), $57-61$.

Donnelly, J. H., Gibson, J. K. \& Ivancevich, J. M. (1984). Fundamentals of management $\left(5^{\text {th }}\right.$ ed.). Texas: business publication Inc.

Ekundayo, J. A. (2015). Impact of training and development on workers' productivity: A study of selected oil service companies in Port Harcourt. International Journal of scientific research in education. 8 (1), 37-47.

Eneh, S. I., Inyang, B. J. \& Ekpe, E. O. (2015). The effect of job training on workers' efficiency and productivity: A study of Pamol Nigeria Limited, Calabar. International journal of management studies and research. $3(1), 57-65$.

Gabriel, J. M. O. \& Rowland, B. M. (2020). Training and employee effectiveness in Port Harcourt City Council, Rivers State, Nigeria. International journal of innovative social sciences and humanities research. 8(1), 33-39.

Greenberg, J. (1996). Quest for justice on the job: Essays and experiments. California: Sage.

Guest, D. E. (1997). Human resource management and performance: A review and research agenda. International journal of human resource management. 8, $265-276$.

Halidu, S. G. (2015). The impact of training and development on workers' productivity in some selected Nigerian Universities. International journal of public administration and management research. 3 (1), 10-16.

Ihunda, C. C. (2002). Advanced management theory and practice. Owerri: Springfield Publishers Ltd.

Mathias, R. L. \& John, H. J. (2003). Human resource management. South-Western: Mason Publishers.

Mathis \& Jackson, J. H. (1982). Personnel: Contemporary perspectives and applications. (3 ${ }^{\text {rd }}$ ed.). St. Paul: West Publishing Company.

McConnell, C. R., Brue, S. L. \& MacPherson, D. A. (2009). Contemporary labour economics. New York: McGraw-Hill.

Mondy, R. W., Noe, R. M. \& Premeaux, S. R. (2002). Human resources management ( $3^{\text {rd }}$ ed.). Upper saddle river, New Jersey: Prentice hall, Inc. 
Neyestani, B. (2014). Impact of training on employee's performance and productivity in construction industry. Retrieved from https://ssrn.com/abstract=2961057.

Nwachukwu, C. (1988). Personnel administration in Nigeria. Port Harcourt: University of Port Harcourt press.

Nwaeke, L. I. \& Obiekwe, O. (2017). Impact of manpower training and development on organizational productivity and performance: A theoretical review. European Journal of business and management. 9(4). Retrieved from http://www.iiste.org/2222-2839/.

Peretomode, V. F. \& Peretomode, O. (2001). Human resource management. Lagos: Obaroh Ogbinaka publishers ltd.

Schultz, T. W. (1961). Investment in human capital. The American economic review. 1, 1-17. Smith, A. (1973). An inquiry into the nature and causes of the wealth of nation. New York: Modern Library.

Tahir, N. Yousafzai, I. K., Jan, S. \& Hashim, M. (2014). The impact of training and development on employees' performance and productivity: A case study of United bank limited, Peshawar City, KPK, Pakistan. International journal of academic research in business and Social Sciences. 4 (4), 86-98.

Torrington, D. Hall, L. \& Taylor, S. (2008). Human resource management ( $7^{\text {th }}$ ed.). England: Pearson Education limited.

Zayum, S. S., Aule, O. \& Teslim, A. B. (2018). Training and employee productivity in the Benue State ministry of agriculture, Nigeria. British Journal of multidisciplinary and advanced studies. $2(1), 1-10$. 